\title{
Subject Review: A Comparison of Using Recycled Rubber as Aggregate in Concrete
}

\author{
${ }^{1}$ Dr. Salam Salman Chiad Alharishawi , ${ }^{2}$ Hadi Salih Mijwel Aljumaily, ${ }^{3}$ Nagham Rajaa \\ ${ }^{1}$ Ph. D., Eng., Department of Environmental Engineering \\ ${ }^{2}$ Assist. Prof., Eng., Department of Environmental Engineering \\ ${ }^{3}$ Assist Lecturer., Eng., Department of Highway and Transportation Engineering \\ ${ }^{123}$ College of Engineering, Mustansiriyah University, Baghdad, Iraq
}

\begin{abstract}
Due to the growth of the population, waste tires have a significant effect on the environmental issue. Every year, the decomposition of waste tire rubber is rapidly rising. Also, recycle rubber scraps into concrete production the main issue could be decreased. Recycle rubber scraps could be combined in concrete by substituting with fine and/or coarse aggregate. Decreasing the fine and coarse aggregate and preserving these natural materials. Furthermore, recycling the rubber scraps avoids the need for tire landfilling, as one of the main environmental problems of the future. A lot of investigation has suggested the use of alternative materials in concrete production, one such material that has gained a lot of attention is the recycled waste tire rubber. This study investigates of existing efforts of the literature studying recycled rubber scraps used as sand and gravel substituting in concrete production and its effect on numerous concrete characteristics.
\end{abstract}

Keywords: Lightweight concrete; Normal weight concrete; Rubber waste; Building materials; Rubber concrete; Rubberized concrete; Recycled rubber.

\section{INTRODUCTION}

The amount of useless waste tires rubber from diverse types of vehicles is fast increasing as one of the significant environmental problems. About one-billion waste tires, rubber is reduced every year [1] and are predicted to be about 1.2 billion every year by $2030[2]$.

Also, many ways of disposing of the waste tires, like landfilling and burning, may cause grave environmental problems, either because of the rapid reduction or air pollution, respectively [3-5]. Since waste rubber scraps have a relatively long lifetime, notice in substituting sand and gravel in concrete production mixtures with waste tires, to afford environmental-friendly concrete with waste rubber scraps. Because of self-compacting rubberized concrete's high ductility, enhanced impact resistance, and energy dissipation characteristics [6], concrete mixed with rubber was used in numerous applications, such as road barriers, sidewalks, pavement [7-9], sports courts, and non-structural applications [10].

The major advantage of this study is to offer an outline of the characteristics of concrete production with substitute sand and gravel with rubber scraps. The fact that sand and gravel make around 50\% of the concrete weight can be used as an encouragement to investigate the effect of substituting sand and gravel with rubber scraps, not only to provide lightweight concrete but also to sustain or even develop the mechanical properties and energy properties.

\section{LITERATURE SURVEY}

Recently, many techniques concerning in recognition have been studied. In this section, we discuss some of these researches.

Rahman et al. [1] and Ganesan et al. [11] pre-treated rubber scraps aggregate with poly-vinyl alcohol and replace15\% of rubber content volume of fine aggregate. A negligible decrease of $3.87 \%$ and $1.12 \%$ in compressive strength of concrete was calculated. In most experimental surveys the substituting level was 15\% [12]. AbdelAleem [13] replaced sand in concrete production mixtures with tires rubber aggregates (with diverse size 0 to $4.75 \mathrm{~mm}$ ). Topcu and Avcular [14] proposed the use of waste tires rubber mixed with concrete. Comparable perceptions were similarly made by Fattuhi [15] and Zhu [16]. Hernandez-Olivares et 
al. [17] discovered that waste tire rubber volume divisions up to $5 \%$ in a concrete outline did not yield a critical difference of the concrete mechanical characteristics.

G.Senthi Kumaran et al. [18] displayed that waste tires and replacement with fine and/or coarse aggregate will make a better value of lightweight concrete. The compressive strength of lightweight concrete decreases with the replacement of waste tires rises [19]. The split tensile of lightweight concrete reduces at the limit of $25 \%$ when rubber substitutes up to $10 \%$ in the sand. The flexural value of lightweight concrete raises when waste tires rubber increases up to $10 \%$. O Youssef [20] suggested that his model can assistance structural designers who are trying to using rubber as a hopeful option in concrete production. R.Bharathi [21] stated that $15 \%$ waste tire rubber is the ideal substituting amount, yet the compressive strength of lightweight concrete is rising, there are a couple of interesting points. Rubber aggregate concrete is concerned with strength, ductility, deflection, and durability [22]. Rubber lightweight concrete is giving better ductility properties than normal concrete.

\section{COMPARATIVE ANALYSIS OF THE LIGHTWEIGHT CONCRETE}

Table 1 Demonstrate the Comparison of using Rubber Waste Replacement (\% by Volume) as Fine Aggregate and Coarse Aggregate In Concrete. Table 2 (\% by weight).

Table 1. Summary of Previous Studies for A Comparison of using Rubber Waste Replacement (\% by Volume) as Fine Aggregate and Coarse Aggregate in Concrete

\begin{tabular}{|c|c|c|c|c|c|}
\hline Ref. & Year & $\begin{array}{l}\text { Rubber Size } \\
\mathrm{mm}\end{array}$ & Replacement of Material & $\begin{array}{l}\text { Comp. } \\
\text { St. } \\
\text { N/mm }\end{array}$ & Research Findings \\
\hline $\begin{array}{l}\text { Bignozzi and } \\
\text { Sandrolini [23] }\end{array}$ & 2006 & $\begin{array}{l}0.5-2.0 \text { and } \\
0.05-0.7\end{array}$ & $\begin{array}{l}22.2 \text { and } 33.3 \% \text { by volume of fine } \\
\text { aggregate }\end{array}$ & 33 & $\begin{array}{l}\text { Reduction of comp. strength (\%) } \\
25 \text { and } 39\end{array}$ \\
\hline $\begin{array}{l}\text { Turatsinze and } \\
\text { Garros [24] }\end{array}$ & 2008 & $4-10$ & $\begin{array}{l}10,15,20 \text { and } 25 \% \text { by volume of } \\
\text { coarse aggregate }\end{array}$ & 45 & $\begin{array}{l}\text { Reduction of comp. strength (\%) } \\
33,54,65 \text { and } 73\end{array}$ \\
\hline $\begin{array}{l}\text { Uyguno glu and } \\
\text { Topçu [25] }\end{array}$ & 2010 & $1-4$ & $\begin{array}{l}10,20,30,40 \text { and } 50 \% \text { by volume of } \\
\text { fine aggregate }\end{array}$ & 25 & $\begin{array}{l}\text { Reduction of comp. strength (\%) } \\
12,32,42,44 \text { and } 48\end{array}$ \\
\hline Güneyisi [26] & 2010 & $0-4$ & $\begin{array}{l}5,15 \text { and } 25 \% \text { by volume of fine } \\
\text { aggregate }\end{array}$ & 73.1 & $\begin{array}{l}\text { Reduction of comp. strength (\%) } \\
21,40 \text { and } 64\end{array}$ \\
\hline Rahman et al. [1] & 2012 & $1-4$ & $28 \%$ by volume of fine aggregate & 21.4 & $\begin{array}{l}\text { Reduction of comp. strength (\%) } \\
30\end{array}$ \\
\hline $\begin{array}{l}\text { Ganesan et al. } \\
{[11]}\end{array}$ & 2013 & $0-4.75$ & $\begin{array}{l}15 \text { and } 20 \% \text { by volume of fine } \\
\text { aggregate }\end{array}$ & 58.86 & $\begin{array}{l}\text { Reduction of comp. strength (\%) } 7 \\
\text { and } 13\end{array}$ \\
\hline Yung et al. [27] & 2013 & $\begin{array}{l}\text { sieve no. } 30 \\
(0.6) \\
\text { sieve no. } 50 \\
(0.3) \\
\text { sieve no. } 30 \\
\text { and no. } 50\end{array}$ & $\begin{array}{l}\text { Sand replaced by volume with } 5,10,15 \\
\text { and } 20 \% \text { rubber waste } \\
\text { Sand replaced by weight with } 5,10,15 \\
\text { and } 20 \% \text { rubber waste } \\
\text { Sand replaced by volume with } 5,10,15 \\
\text { and } 20 \% \text { rubber waste }\end{array}$ & 32.07 & $\begin{array}{l}\text { Reduction of comp. strength (\%) } \\
10,22,16 \text { and } 29 \\
\text { Reduction of comp. strength (\%) } 4 \text {, } \\
27,27 \text { and } 32 \\
\text { Reduction of comp. strength (\%) } \\
19,25,40 \text { and } 40\end{array}$ \\
\hline Ismail et al. [28] & 2015 & $<4.75$ & $\begin{array}{l}5,10,15,20,30 \text { and } 40 \% \text { by volume } \\
\text { of fine aggregate }\end{array}$ & 53.5 & $\begin{array}{l}\text { Reduction of comp. strength (\%) } \\
12,19,28,39,50 \text { and } 61\end{array}$ \\
\hline Khalil et al. [29] & 2015 & $0-2$ & $\begin{array}{l}10,20,30 \text { and } 40 \% \text { by volume of fine } \\
\text { aggregate }\end{array}$ & 27 & $\begin{array}{l}\text { Reduction of comp. strength (\%) } \\
17,26,37 \text { and } 40\end{array}$ \\
\hline
\end{tabular}


International Journal of Advances in Scientific Research and Engineering (ijasre), Vol 7 (2), February -2021

\begin{tabular}{|c|c|c|c|c|c|}
\hline $\begin{array}{l}\text { Ismail and } \\
\text { Hassan [4] }\end{array}$ & 2016 & $0-4$ & $\begin{array}{l}5,10,15,20,25,30 \text { and } 40 \% \text { by } \\
\text { volume of fine aggregate }\end{array}$ & $\begin{array}{l}52.95 \\
\text { and } 40\end{array}$ & $\begin{array}{l}\text { Reduction of comp. strength }(\%) \\
16,21,29,42,46,53 \text { and } 67\end{array}$ \\
\hline Zaoiai et.al [30] & 2016 & $\begin{array}{l}0 / 3 \\
3 / 8\end{array}$ & $\begin{array}{l}5 \% \text { by volume of fine aggregate } \\
20 \% \text { by volume of coarse aggregate }\end{array}$ & 37.9 & $\begin{array}{l}\text { Reduction of comp. strength (\%) } \\
37 \\
\text { Reduction of comp. strength }(\%) \\
36\end{array}$ \\
\hline $\begin{array}{l}\text { Güneyisi et al. } \\
\text { [31] }\end{array}$ & 2016 & $\begin{array}{l}<1 \\
1-4 \\
<4 \\
10-40 \\
\text { length }\end{array}$ & $\begin{array}{l}5,10,15,20 \text { and } 25 \% \text { by volume of } \\
\text { coarse aggregate }\end{array}$ & 62.8 & $\begin{array}{l}\text { Reduction of comp. strength (\%) } 7 \text {, } \\
18,24,31 \text { and } 39 \\
\text { Reduction of comp. strength (\%) } \\
\text { 15, 21, 29, } 42 \text { and } 50 \\
\text { Reduction of comp. strength (\%) } \\
\text { 13, 20, 27, } 35 \text { and } 42 \\
\text { Reduction of comp. strength }(\%) \\
17,29,36,45 \text { and } 51\end{array}$ \\
\hline $\begin{array}{l}\text { Ismail and } \\
\text { Hassan [32] }\end{array}$ & 2016 & $<4.75$ & $\begin{array}{l}\text { coarse aggregate replaced by volume } \\
\text { with } 5,10,15,20 \text { and } 25 \% \text { rubber } \\
\text { waste }\end{array}$ & 75.65 & $\begin{array}{l}\text { Reduction of comp. strength }(\%) \\
12,29,41,49,51 \text { and } 58\end{array}$ \\
\hline $\begin{array}{l}\text { Bideci et al. } \\
{[12]}\end{array}$ & 2017 & $\begin{array}{l}\text { Length-25 } \\
\text { Length-50 } \\
\text { Length-75 }\end{array}$ & $\begin{array}{l}5,10 \text { and } 15 \% \text { by volume of coarse } \\
\text { aggregate }\end{array}$ & 53.8 & $\begin{array}{l}\text { Reduction of comp. strength (\%) } \\
17,20 \text { and } 47 \\
\text { Reduction of comp. strength (\%) } \\
52,54 \text { and } 52 \\
\text { Reduction of comp. strength (\%) } \\
60,61 \text { and } 58\end{array}$ \\
\hline Hilal [33] & 2017 & $\begin{array}{l}0-1 \\
1-4 \\
0-4\end{array}$ & $\begin{array}{l}5,10,15,20 \text { and } 25 \% \text { by volume of } \\
\text { fine aggregate }\end{array}$ & 72.44 & $\begin{array}{l}\text { Reduction of comp. strength (\%) } 6 \text {, } \\
12,16,21 \text { and } 31 \\
\text { Reduction of comp. strength }(\%) \\
38,18,26,37 \text { and } 46 \\
\text { Reduction of comp. strength }(\%) 0 \text {, } \\
10,15,21 \text { and } 32\end{array}$ \\
\hline $\begin{array}{l}\text { Aslani et al. } \\
{[34]}\end{array}$ & 2018 & $5-10$ & $20 \%$ by volume of coarse aggregate & 50.39 & $\begin{array}{l}\text { Reduction of comp. strength (\%) } \\
56\end{array}$ \\
\hline Si et al. [8] & 2018 & $1.44-2.83$ & $\begin{array}{l}15 \text { and } 25 \% \text { by volume of fine } \\
\text { aggregate }\end{array}$ & 65 & $\begin{array}{l}\text { Reduction of comp. strength (\%) } \\
33 \text { and } 52\end{array}$ \\
\hline $\begin{array}{l}\text { AbdelAleem et } \\
\text { al. [35] }\end{array}$ & 2018 & $<4.75$ & $\begin{array}{l}\text { Sand replaced by volume with } 5,10 \text {, } \\
15,20 \text { and } 25 \% \text { rubber waste }\end{array}$ & 75.7 & $\begin{array}{c}\text { Reduction of comp. strength }(\%) \\
12,29,41,49,51 \text { and } 58\end{array}$ \\
\hline $\begin{array}{l}\text { Aslani et al. } \\
\text { [36] }\end{array}$ & 2018 & 5 & $\begin{array}{l}\text { Sand replaced by volume with } 10,20 \text {, } \\
30 \text { and } 40 \% \text { rubber waste } \\
\text { Sand replaced by volume with } 10,20 \text {, } \\
30 \text { and } 40 \% \text { rubber waste }\end{array}$ & 50.39 & $\begin{array}{l}\text { Reduction of comp. strength (\%) } \\
29,41,49 \text { and } 61 \\
\text { Reduction of comp. strength }(\%) \\
19,34,41 \text { and } 48\end{array}$ \\
\hline
\end{tabular}




\begin{tabular}{|l|l|l|l|l|l|}
\hline & & 10 & $\begin{array}{l}\text { coarse aggregate replaced by volume } \\
\text { with 10, 20,30 and 40\% rubber waste }\end{array}$ & $\begin{array}{l}\text { Reduction of comp. strength (\%) } \\
38,56,62 \text { and } 67\end{array}$ \\
\hline $\begin{array}{l}\text { AbdelAleem } \\
\text { and Hassan [13] }\end{array}$ & 2019 & $<4.75$ & $\begin{array}{l}\text { Sand replaced by volume with 5, 10, 15 } \\
\text { and 20\% rubber waste }\end{array}$ & 80.15 & $\begin{array}{l}\text { Reduction of comp. strength (\%) } \\
22,39,48 \text { and 58 }\end{array}$ \\
\hline
\end{tabular}

Table 2. Summary of Previous Studies for A Comparison of using Rubber Waste Replacement (\% by Weight) as Fine Aggregate and Coarse Aggregate in Concrete

\begin{tabular}{|c|c|c|c|c|c|}
\hline Ref. & Year & $\begin{array}{l}\text { Rubber } \\
\text { Size } \\
\text { mm }\end{array}$ & $\begin{array}{l}\text { Replacement of Material } \\
\text { (\% by Weight) }\end{array}$ & $\begin{array}{l}\text { Comp. } \\
\text { Strength } \\
\text { N/mm² }\end{array}$ & Research Findings \\
\hline $\begin{array}{l}\text { Topçu and } \\
\text { Bilir [37] }\end{array}$ & 2009 & $0-4$ & $\begin{array}{l}8,16.90 \text { and } 26.87 \% \text { by } \\
\text { weight of fine aggregate }\end{array}$ & 50.3 & $\begin{array}{l}\text { Reduction of comp. strength (\%) } 23,40 \\
\text { and } 71\end{array}$ \\
\hline $\begin{array}{l}\text { Najim and } \\
\text { Hall [38] }\end{array}$ & 2012 & $2-6$ & $\begin{array}{l}5 \% \text { by weight of fine } \\
\text { aggregate } \\
10 \% \text { by weight of coarse } \\
\text { aggregate } \\
15 \% \text { by weight of fine and } \\
\text { coarse aggregate }\end{array}$ & 55 & $\begin{array}{l}\text { Reduction of comp. strength (\%) } 33,42 \\
\text { and } 53 \\
\text { Reduction of comp. strength (\%) } 18,40 \\
\text { and } 58 \\
\text { Reduction of comp. strength (\%) } 18,31 \\
\text { and } 49\end{array}$ \\
\hline $\begin{array}{l}\text { Emiro } \breve{g l u} \\
\text { et al. [3] }\end{array}$ & 2012 & $5-12$ & $\begin{array}{l}15,30,45 \text { and } 60 \% \text { by } \\
\text { weight of coarse aggregate }\end{array}$ & 71.6 & $\begin{array}{l}\text { Reduction of comp. strength (\%) } 11,34 \text {, } \\
54 \text { and } 65\end{array}$ \\
\hline $\begin{array}{l}\text { Mishra } \\
\text { and Panda } \\
{[39]}\end{array}$ & 2015 & $\begin{array}{l}5 \text { and } \\
10\end{array}$ & $\begin{array}{l}5,10,15 \text { and } 20 \% \text { by weight } \\
\text { of coarse fine aggregate }\end{array}$ & 65.4 & $\begin{array}{l}\text { Reduction of comp. strength }(\%) 11,31 \text {, } \\
39 \text { and } 47\end{array}$ \\
\hline
\end{tabular}

\section{CONCLUSIONS}

In this research article, various approaches have been reviewed for lightweight concrete made with rubber within the period (2006-2019). Using sawdust becomes very significant in the production of lightweight concrete. The previous investigations have established that the combination of waste tire rubber in concrete as substituting for sand and gravel decreases the compressive quality. Researches similarly show that the mechanical properties of tire rubber aggregate concrete are extremely influenced by the size, extent and surface of the waste tire rubber and the type of cement, also the size of the sand and gravel utilized. Rubber is considered a waste material and can use to make lightweight concrete and which possesses heat transfer of long duration. Moreover, it is the perfect way to reduce sold wood waste and produce lightweight concrete to be used in industrial construction. Every experimental study has some disadvantages and benefits and thus novel technologies have been sophisticated.

\section{Acknowledgments}

The author would like to thank Mustansiriyah University, in Baghdad, Iraq, for their help in this work.

\section{REFERENCES}

1. Rahman:, M.M.; Usman, M.; Al-Ghalib, A.A. (2012). Fundamental properties of rubber modified self-compacting concrete (RMSCC). Constr. Build. Mater. 36, 630-637. 
2. Liu, H.;Wang, X.; Jiao, Y.; Sha, T. (2016). Experimental investigation of the mechanical and durability properties of crumb rubber concrete. Materials. 9, 172.

3. Emiro glu, M.; Yildiz, S.; Kele,stemur, O.; Kele,stemur, M.H. Bond performance of rubber particles in the selfcompacting concrete. (2012). In Proceedings of the 4th International Symposium Bond in Concrete 2012-Bond, Anchorage, Detailing, Brescia, Italy, 17-20 June 2012; pp. 779-785.

4. Ismail, M.K.; Hassan, A.A.A. (2016). Use of metakaolin on enhancing the mechanical properties of self-consolidating concrete containing high percentages of crumb rubber. J. Clean. Prod. 125, 282-295.

5. Geso` glu, M.; Güneyisi, E.; Khoshnaw, G.; Ipek, S. (2014). Investigating properties of pervious concretes containing waste tire rubbers. Constr. Build. Mater. 63, 206-213.

6. Elghazouli, A.Y.; Bompa, D.V.; Xu, B.; Ruiz-Teran, A.M.; Stafford, P.J. (2017). Performance of rubberised reinforced concrete members under cyclic loading. Eng. Struct. 166, 526-545.

7. Moustafa, A.; Elgawady, M.A. (2015). Mechanical properties of high strength concrete with scrap tire rubber. Constr. Build. Mater. 93, 249-256.

8. Si, R.; Wang, J.; Guo, S.; Dai, Q.; Han, S. (2018). Evaluation of laboratory performance of self-consolidating concrete with recycled tire rubber. J. Clean. Prod. 180, 823-831. [CrossRef]

9. Jedidi, M.; Gargouri, A.; Daoud, A. (2014). Effect of Rubber Aggregates on the Thermophysical Properties of SelfConsolidating Concrete. Int. J. Therm. Environ. Eng. 8, 1-7.

10. Murugan, R.B.; Sai, E.R.; Natarajan, C.; Chen, S.E. (2017). Flexural fatigue performance and mechanical properties of rubberized concrete. Graevinar 69, 983-990.

11. Ganesan,N.;BharatiRaj,J.;Shashikala,A.P.(2013). Flexural fatigue behaviorof self-compacting rubberized concrete. Constr. Build. Mater. 44, 7-14.

12. Bideci, A.; Öztürk, H.; Bideci, Ö.S.; Emirog $־$ lu, M. (2017). Fracture energy and mechanical characteristics of selfcompacting concretes including waste bladder tyre. Constr. Build. Mater. 149, 669-678.

13. AbdelAleem, B.H.; Hassan, A.A.A. (2018). Development of self-consolidating rubberized concrete incorporating silica fume. Constr. Build. Mater. 2018, 161, 389-397.

14. Topcu, I.B. and Avcular, N. (1997). Collision behaviors of rubberized concrete. Cement and Concrete Research 27 (12), pp.1893-1898.

15. Fattuhi, N.I. and Clark, N.A. . (1996). Cement-based materials containing tire rubber. Journal of Construction and Building Materials, Vol.10, No.4, pp.229-236.

16. Zhu, A.H. (1997). Florida's Experience Utilizing Crumb Tyre Rubber in Road Pavements. National Seminar on Asphalt Rubber, Cansas City, Missouri, pp.499-535.

17. Hernandez-olivares, F., Barluenga, G., Bollati, M. and Witoszek, B. (2002). Statics and dynamic behaviuour of recycled tyre rubber-filled concrete. Cem. Concr. Res., 32: pp.1587-1596.

18. Senthi Kumaran, G., Nurdin Mushule and Lakshmipathy, M. (2008). A Review on Construction Technologies that Enables Environmental Protection: Rubberized Concrete. American Journal of Engineering and Applied Science, 1 (1), pp.40-44.

19. Nithya P,Portchejian G. (2014).Behavior of Partial Replacement of Fine Aggregate with Crumb Rubber Concrete",International Journal of Structural and Civil Engineering Research. Vol. 3, Issue 3, pp.63-72.

20. Youssf, O, ElGawady, MA, Mills, JE \& Ma, X . (2014). Prediction of crumb rubber concrete strength', in ST Smith (ed.), 23rd Australasian Conference on the Mechanics of Structures and Materials (ACMSM23), vol. I, Byron Bay, NSW, $9-12$ December, Southern Cross University, Lismore, NSW, pp.261-266. ISBN: 9780994152008.

21. Bharathi Murugan R., Natarajan C. (2015) Investigation of the Behaviour of Concrete Containing Waste Tire Crumb Rubber. In: Matsagar V. (eds) Advances in Structural Engineering. Springer, New Delhi.

22. Senthil Vadivel, T. \& Thenmozhi, R. (2012). Experimental study on waste tyre rubber replaced concrete - an ecofriendly construction material, Journal of Applied Sciences Research, Vol. 8, No. 6, pp. 2966-2973

23. Bignozzi, M.C.; Sandrolini, F. (2006). Tyre rubber waste recycling in self-compacting concrete. Cem. Concr. Res. 36, 735-739. 
24. Turatsinze, A.; Garros, M. (2008). On the modulus of elasticity and strain capacity of Self-Compacting Concrete incorporating rubber aggregates. Resour. Conserv. Recycl. 52, 1209-1215.

25. Uyguno glu, T.; Topçu, I.B. (2010). The role of scrap rubber particles on the drying shrinkage and mechanical properties of self-consolidating mortars. Constr. Build. Mater. 24, 1141-1150.

26. Güneyisi, E. (2010). Fresh properties of self-compacting rubberized concrete incorporated with fly ash.Mater. Struct. Constr. 43, 1037-1048.

27. Yung, W.H.; Yung, L.C.; Hua, L.H. (2013). A study of the durability properties of waste tire rubber applied to selfcompacting concrete. Constr. Build. Mater. 41, 665-672.

28. Ismail, M.K.; De Grazia, M.T.; Hassan, A.A.A. (2015). Mechanical properties of self-consolidating rubberized concrete with different supplementary cementing materials. In Proceedings of the International Conference on Transportation and Civil Engineering (ICTCE'15), London, UK, 21-22 March; pp. 68-75.

29. Khalil, E.; Abd-Elmohsen, M. (2015). Anwar, A.M. Impact Resistance of Rubberized Self-Compacting Concrete. Water Sci. $29,45-53$.

30. Zaoiai, S.; Makani, A.; Tafraoui, A. (2016). Benmerioul, F. Optimization and mechanical characterization of selfcompacting concrete incorporating rubber aggregates. Asian J. Civ. Eng. 17, 817-829.

31. Güneyisi, E.; Gesoglu, M.; Naji, N.; Ipek, S. (2016). Evaluation of the rheological behavior of fresh self-compacting rubberized concrete by using the Herschel-Bulkley and modified Bingham models. Arch. Civ. Mech. Eng. 16, 9-19.

32. Ismail, M.K.; Hassan, A.A.A. (2016). Impact Resistance and Mechanical Properties of Self-Consolidating Rubberized Concrete Reinforced with Steel Fibers. J. Mater. Civ. Eng. 29, 04016193.

33. Hilal, N.N. (2017). Hardened properties of self-compacting concrete with different crumb rubber size and content. Int. J. Sustain. Built Environ. 6, 191-206.

34. Aslani, F.; Ma, G.; Wan, D.L.Y. (2018). Muselin, G. Development of high-performance self-compacting concrete using waste recycled concrete aggregates and rubber granules. J. Clean. Prod. 182, 553-566.

35. AbdelAleem, B.H.; Ismail, M.K.; Hassan, A.A.A. (2018). The combined effect of crumb rubber and synthetic fibers on impact resistance of self-consolidating concrete. Constr. Build. Mater. 162, 816-829.

36. Aslani, F.; Ma, G.; YimWan, D.L.; Tran Le, V.X. (2018). Experimental investigation into rubber granules and their effects on the fresh and hardened properties of self-compacting concrete. J. Clean. Prod. 172, 1835-1847.

37. Topçu, I.B.; Bilir, T. (2009). Experimental investigation of some fresh and hardened properties of rubberized selfcompacting concrete. Mater. Des. 30, 3056-3065.

38. Najim, K.B.; Hall, M.R. (2012). Mechanical and dynamic properties of self-compacting crumb rubber modified concrete. Constr. Build. Mater. 27, 521-530.

39. Mishra, M.; Panda, K.C. (2015). An Experimental Study on Fresh and Hardened Properties of Self Compacting Rubberized Concrete. Indian J. Sci. Technol. 8.

\section{Author emails:}

${ }^{1}$, Dr. Salam Salman Chiad Alharishawi, e-mail: dr.salam.chiad@uomustansiriyah.edu.iq

${ }^{1}$ Hadi Salih Mijwel Aljumaily, e-mail: hadi.aljumaily@uomustansiriyah.edu.iq

1, Nagham Rajaa , e-mail: Nagham_z77@uomustansiriyah.edu.iq 